\title{
ANALISIS HASIL PENERJEMAHAN KATA SLANG DALAM DIALOG FILM DEADPOOL 2 BERDASARKAN GENDER PENERJEMAH
}

\author{
Muhammad Aprianto Budie Nugroho \\ Program Studi Pendidikan Bahasa Inggris, FKIP \\ Universitas Kuningan \\ muh.apriantobn@gmail.com
}

\begin{abstract}
ABSTRAK: Didalam penelitian ini peneliti fokus dalam menganalisis perbedaan dalam hasil penerjemahan kata slang terdapat pada dialog fim Deadpool 2 yang dilakukan oleh para partisipan yang dibedakan berdasarkan gender para penerjemah. Selain hal tersebut peneliti juga berusaha mencari tahu kesetaraan makna yang terdapat dalam hasil penerjemahan yang dilakukan oleh para partisipan. Penelitian ini menggunakan metode penelitian kualitatif dengan desain penelitian studi kasus. Partisipan yang terlibat dama penelitian ini adalah mahasiswa pria dan wanita dari tingkat 3 pada semester 5. Data penelitian adalah berupa dokumen penerjemahan yang dilakukan oleh para partisipan. Hasil dari penelitian tersebut adalah hasil penerjemahan kata slang yang dilakukan oleh partisipan pria total terdapat 37 persamaan dari 4 partisipan dalam menerjemahkan kata slang, dan yang diterjemahkan berbeda oleh 4 partisipan terdapat total 28 perbedaan, sedangkan pada hasil penerjemahan 4 partisipan wanita terdapat 40 persamaan dalam menerjemahkan 18 kata slang, dan terdapat 27 perbedaan dalam menerjemahkan katakata tersebut. Sedangkan untuk kesetaraan baik dalam kata, gramatikal, tekstual dan pragmatik, baik partisipan pria maupun partisipan wanita dalam menerjemahkan hampir semua mencapai partisipan telah mencapai kesetaran/kesepadanan baik pada tingkat kata, gramatikal, tekstual, dan pragmatik. Dalam kesetaraan kata totalnya adalah 52 kesetaraan dari total 8 partisipan. Sedangkan untuk kesetaraan gramatikal total kesetaraannya terdapat 44 kesetaraan/kesepadanan dari total 8 partisipan pria dan wanita. Untuk kesetaraan tekstual terdapat 51 kesetaraan dari 8 partisipan pria dan wanita. Sedangkan untuk kesetaraan pragmatik terdapat 50 kesetaraan dari total 8 partisipan pria dan wanita.

KATA KUNCI: Komparatif; Kata Slang; Gender; Kesetaraan makna.
\end{abstract}

\section{ANALYSIS OF SLANG WORD TRANSLATION RESULTS IN THE DEADPOOL 2 FILM DIALOGUE BASED ON TRANSLATION GENDER}

\begin{abstract}
In this research, the reseacher focuses on anlayzing the differences on translation result in translating slang words in the movie entitled Deadpool 2 conducted by partisipants based on their gender. In this reserach the researcher also find out the translation equivalence in the translation result conducted by all the particpants. Qualitative method with case study design is used in this reserach. There are ten partcipants are involved in this reserach, they are four male students and four female students in third degree, in the fifth semester. The data of the reserach is in the form translation results conducted by all eight participants. The result of the research are from 18 slang words in the dialog in the movie there are 11 similarities from 4 male participants, and there are 21 differences in translating slang words by 4 male participants. The translation result from female partcipants there are 40 similarities in translating 18 slang words and 27 differences in translating slang words by 4 female participants. Meanwhile on the translation equivalent almost all the particpants achieve translation equivalence, there are 52 equivalences in word from 8 participants, 44 equivalences for grammatical equivalence, 51 texstual equivalences and 50 pragmatik equivalances from 8 males and females participants.
\end{abstract}

KEYWORDS: Comparative; Slang Words; Gender; Translation Equivalence.

\begin{tabular}{lccc}
\hline Diterima: & Direvisi: & Disetujui: & Dipublikasi: \\
23-11-2019 & 18-03-2020 & $20-03-2020$ & $31-03-2020$ \\
Pustaka & : Nugroho, M. A. B. (2020). ANALISIS KOMPARATIF PENERJEMAHAN KATA SLANG \\
& DALAM DIALOG DI FILM DEADPOOL 2 BERDASARKAN GENDER PENERJEMAH. \\
& Fon: Jurnal Pendidikan Bahasa dan Sastra Indonesia, 16(1), 1-9. \\
DOI & $:$ https://doi.org/10.25134/fjpbsi.v16i1.2156 & \\
\hline
\end{tabular}




\section{PENDAHULUAN}

Penerjemahan adalah sebuah aktivitas ketika seseorang translator menerjemahkan kedalam bahasa target secara akurat. Akurasi sangat dibutuhkan dalam proses dalam penerjemahan dengan tujuan untuk menghasilkan sebuah hasil penerjemahan yang bagus dan akurat. Catford (1962, Hlm. 20) berpendapat bahwa bahwa menerjemahkan adalah mengganti materi textual di dalam suatu bahasa (Bahasa Sumber) dengan materi textual yang equivalent atau setara di dalam bahasa target. Menurut Newmark (1988, Hlm. 5) penerjemahan mempunyai beberapa makna, tapi secara garis besar adalah memberikan makna pada suatu teks dari bahasa satu kedalam bahasa lain sesuai dengan yang diinginkan oleh penulis/pengarang di dalam teks.

Pada saat ini, karya-karya sastra asing adalah salah satu produk yang banyak diterjemahkan kedalam bahasa Indonesia. Salah satu dari produk sastra adalah film. Menurut Klarer (2004) bahwa film dikategorikan sebagai bagian dari performing arts karena film melibatkan aktor dalam menyampaikan/mengekspresikan gagasan. Selain itu dia menambahkan bahwa film mempunyai kekuatan visual dan membutuhkan presentasi yang lebih seperti angle kamera, editing, gerakan cepat dan lambat, direkam dengan suara yang menceritakan mengenai cerita tertentu. Sedangkan Vassiliou (2006) menyatakan bahwa, "Film mempersembahkan kita dengan cerita atau narasi yang menceritakan kembali melalui interaksi antar karakter". Selain itu film juga salah satu medium untuk menyampaikan pesan kepada publik dan juga media untuk mempengaruhi publik.

Dalam menerjemahkan dialog film bukansaja membutuhkan kemampuan memahami bahasa sumber (BSu), tapi juga dibutuhkan kemampuan menuliskan kembali/menerjemahkan dalam bahasa target (BTa). Penerjemahan terutama dalam menerjemahkan dialog film membutuhkan pemamahan yang komprehensif dari seorang penerjemah dalam memahami bahasa sumber, tetapi juga mampu mencari padanan kata, idiom atau prasa yang sesuai dalam menerjemahkan sebuah karya sastra dari bahasa sumber (BSu) kedalam bahasa target (BTa).

Di dalam penelitian ini peneliti ingin mengetahui mengenai perbedaan penerjemahan kata-kata slang yang dilakuan oleh para mahasiswa dalam menerjemahkan dialog film dari film berjudul Deadpol 2 berdasarkan gender/jenis kelamin dari para penerjemah. Kenapa penelitian ini fokus pada hasil penerjemahan yang dilakukan oleh penerjemah mahasiswa laki-laki dan wanita, karena ada kaitan antara gender dengan studi penerjemahan, di dalam penelitian yang dilakukan oleh Fairus dan Fauzi (2017, Hlm. 275-276) menyatakan bahwa perbedaan gender akan mempengaruhi variasi-variasi penggunaan bahasa, secara operasional laki-laki dan wanita cenderung menggunakan variasi bahasa secara berbeda. Hal tersebut disebabkan pada hasil penelitian yang menyebutkan bahwa ada perbedaan pada otak laki-laki dan wanita.

Penelitian kedua dilakukan oleh Halimah (2016) yang berjudul Gender Creative Translation: which is better? A case Study of Saudi Learners. Di dalam penelitiaannya dia membuat hypothesis bahwa para pelajar wanita Arab Saudi cenderung mampu menerjemahkan jauh lebih baik dari rekan laki-laki mereka dalam menerjemahkan puisi. Di dalam penelitiannya, peneliti memberikan tes untuk membuktikan hypotesisnya, dan hasil dari penerjemahan memperlihatkan bahwa hasil penerjemahan yang dilakukan oleh pelajar wanita Arab Saudi lebih baik daripada hasil penerjemahan yang dilakukan oleh rekan laki-laki mereka. 
Selain itu terdapat penelitian yang meneliti mengenai hasil penerjemahan yang dilakukan oleh penerjemah pria dan wanita. Penelitian tersebut dilakukan oleh Amanati (2016) yang berjudul The Translator's Gender and its Impacts on Translation Accuracy of Narrative Style, penelitian yang dilakukan oleh Amanati adalah menguji keakurasian penerjemahan berdasarkan gender penerjemah. Berdasarkan hasil penerjemahannya bisa diambil sebuah kesimpulan bahwa latar belakang gender dari penerjemah tidak berpengaruh dalam akurasi penerjemahan mereka.

Penelitian-penelitian sebelumnya lebih fokus pada kualitas penerjemahan berdasarkan gender penerjemah sedangkan dalam penelitian ini Peneliti lebih fokus untuk meneliti hasil penerjemahan kata-kata slang yang terdapat dalam dialog film yang berjudul Deadpool 2 dari bahasa Ingris kedalam bahasa Indonesia yang dilakukan antara mahasiswa laki-laki dan wanita di kelas penerjemahan Indonesia-Inggris di Prodi Pendidikan Bahasa inggris, Fakultas Keguruan dan Ilmu Pendidikan Universitas Kuningan.

\section{METODE}

Di dalam penelitian ini peneliti menggunakan metode penelitian kualitatif, menurut Creswell (2009, Hlm. 4) bahwa penelitian kualitatif adalah sebuah proses mengeksplorasi sebuah permasalahan baik permasalahan sosial atau individu. Proses penelitian berdasarkan pertanyaan-pertanyan yang muncul dan prosedur-prosedur yang diambil, data biasanya diambil dari setting partisipan, basis data diambil secara induktif dari khusus ke umum, dan peneliti mengintepretasi makna dari datadata tersebut. Laporan akhir dari penelitaian kualitatif mempunyai struktur yang fleksibel.
Darlington dan Scott (2003, Hlm. 3) menambahkan bahwa penelitian kualitatif adalah bagaimana peneliti membangun pertanyaan, dan mengerjakan melalui daerah yang terjal baik secara etika dan politik, secara sistematis mengumpulkan data yang sesuai, menganalisisnya secara kaku dan menyebarkan hasil temuan dan implikasi dari penelitian.

Desain penelitian dalam penelitian ini adalah desain penelitian studi kasus. Penelitian studi kasus adalah sebuah merupakan desain penelitian yang ditemukan dalam berbagai bidang, khususnya evaluasi, dimana peneliti mengembangkan analisis mendalam mengenai suatu kasus baik itu program, peristiwa, aktivitas, proses atau satu individu (Creswell, 2016). Penelitian ini akan difokuskan bagaimana para mahasiswa laki-laki dan mahasiswa wanita dalam menterjemahkan kata-kata slank yang terdapat didalam diaog di film Deadpool 2. Serta mengetahui kesetaraan makna dalam hasil terjemahan kata slang yang dilakukan oleh para mahasiswa berdasarkan gender mereka.

Penelitian ini akan mengambil tempat di Universitas Kuningan tepatnya di Program Studi Pendidikan Bahasa Inggris, di Fakultas Keguruan dan Ilmu Pendidikan. Pendidikan bahasa Inggris. Partisipan di dalam penelitian ini adalah 4 mahasiswa pria dan 4 mahasiswa wanita Prodi Pendidikan Bahasa Inggris pada tingkat 3. Pemilihan partisipan didasarkan pada alasan bahwa mahasiswa pada tingkat ini sudah mendapatkan mata kuliah penerjemahan, sehingga dianggap mampu untuk menerjemahkan teks yang tingkat kesulitannya tinggi.

Tekhnik pengumpulan data berdasarkan dokumen yang di dapatkan melalui hasil penerjemahan para partisipan dalam menerjemahkan katakata slang yang terlibatdalam penelitian ini. 


\section{HASIL DAN PEMBAHASAN}

Di dalam penelitian ini, peneliti akan melakukan analisa komparatif dari penerjemahan kata-kata slang yang dilakukan oleh para mahasiswa berdasarkan gender dari para penerjemah, apakah terdapat perbedaan dalam hasil penerjemahan kata-kata slang yang dilakukan oleh mahasiswa pria dan wanita di Jurusan pendidian Bahasa Inggris, FKIP, Universitas Kuningan. Terdapat 65 kata slang yang terdapat dalam film tersebut, di dalam penelitian ini peneliti hanya menggunakan 18 kata slang dalam tujuh belas prasa dan kalimat yang diterjemahkan oleh para partisipan.

Berdasarkan data penerjemahan yang didiapat dari hasil penerjemahan mahasiswa pria dan wanita ditemukan, bahwa hasil penerjemahan kata slang yang dilakukan oleh partisipan pria total terdapat 11 persamaan dari 4 partisipan dalam menerjemahkan kata slang, dan yang diterjemahkan berbeda oleh 4 partisipan terdapat total 21 perbedaan, sedangkan pada hasil penerjemahan 4 partisipan wanita terdapat 40 persamaan dalam menerjemahkan 18 kata slang, dan terdapat 27 perbedaan dalam menerjemahkan kata-kata tersebut.

Pemaparan data pertama dalam penelitian ini adalah hasil penerjemahan kata-kata slang yang terdapat pada dialog pertama di waktu (00:02:13). Kata slang yang terdapat di dalam dialog tersebut adalah slang, yaitu terdapat pada frasa "fuck wolverine".

Hal yang menarik muncul dari hasil penerjemahan yang dilakukan oleh masing-masing partisipan baik dari pihak mahasiswa pria maupun wanita, partisipan pria 2, dan partisipan wanita 5 dan 6 menerjemahkan kata fuck kedalam bahasa Indonesia dengan menggunakan kata Dasar. Sedangkan partisipan pria 3 dan partisipan wanita 7 menerjemahkan kata fuck kedalam bahasa Indonesia dengan menggunakan kata sialan, partisipan pria
4 dan partisipan wanita 8 menerjemahkan kata fuck kedalam bahasa Indonesia dengan menggunakan kata brengsek, dan yang terakhir hanya partisipan pria 1 satu yang menerjemahkan kata fuck dengan menggunakan kata persetan.

Selanjutnya hasil penerjemahan dari kalimat dialog bahasa Inggris pada menit 00:02:21 yaitu Then the hairy motherfucker ups the ante by dying, kata slang yang terdapat pada kalimat tersebut adalah motherfucker. Dibawah ini adalah hasil penerjemahan yang dilakukan oleh para partisipan dalam menerjemahkan kata slang tersebut.

Dari hasil penerjemahan yang dilakukan oleh para mahasiswa pria dan wanita bisa dibandingkan pada hasil penerjemahan dalam menerjemahkan kata slang motherfucker yaitu untuk partisipan pria 1 memilih untuk tidak menerjemahkan kata motherfucker, sedangkan partisipan 2 pria, dan partisipan wanita 5, 6, 7, 8 menerjemahkan kata motherfucker kedalam bahasa Indonesia dengan kata Bajingan, sedangkan partisipan 3 memilih menerjemahkan kata tersebut dengan dua kata bahasa Indonesia yaitu brengsek bajingan. Untuk partisipan pria 4 memilih menggunakan kata brengsek dalam menerjemahkan kata motherfucker.

Penerjemahan selanjutnya adalah $I$ don't bargain, pumpkin fucker, yang pumpin fucker (00:03:17) adalah kata slang. Dibawah ini adalah hasil penerjemahan yang dilakukan oleh para partisipan, baik partsispan pria maupun wanita dalam menerjemahkan kata slang tersebut.

Berdasarkan hasil penerjemahan yang dilakukan baik oleh partisipan mahasiswa pria maupun wanita dalam menerjemahkan kata pumpkin fucker dari bahasa Inggris ke dalam bahasa Indonesia maka bisa dilihat bahwa hanya partisipan mahasisa pria 1 yang memilih tidak menerjemahkan pumpkin fucker. Hal yang 
menarik adalah hasil penerjemahan yang dilakukan oleh partisipan pria 2 memilih menerjemahkan pumpkin fucker dengan kata bajingan yang kata tersebut juga digunakan oleh partisipan perempuan 5, 6 . Untuk partisipan 3 menggunakan kata bodoh untuk menerjemahkan kata slang tersebut. Partisipan pria 4 menerjemahkan kata pumpin fucker dengan menggunakan kata keparat, kata tersebut juga digunakan oleh partisipan wanita 8 dalam menerjemahkan kata yang sama, sedangkan partispan 7 lebih memilih menggunakan kata anjing dalam menerjemahkan kata pumpkin fucker.

Kalimat selanjutanya yang harus diterjemahkan oleh para partisipan adalah Uh, that's so gross (00:04:37). Kata slang yang terdapat dalam kalimat tersebut adalah gross berikut ini adalah hasil penerjemahan yang dilakukan oleh partisipan pria dan wanita.

Pada hasil penerjemahan yang dilakukan oleh para partisipan bisa dilihat bahwa hampir sebagian besar menerjamahkan kata gross dengan kata yang sama, hal tersebut bisa dilihat dari hasil penerjemahan partisipan pria 1, 2, 4 dan partisipan wanita $5,6,8$ yang menerjemahkan kata gross dengan menggunakan kata menjijikan. Sedangkan untuk partisipan pria 3 lebih memilih menerjemahkan kata gross dengan kata norak, untuk partisipan 7 memilih kata jijik banget untuk menerjemahkan kata gross.

Kalimat selanjutanya yang harus diterjemahkan dari bahasa sumber kedalam bahasa target oleh para partisipan adalah holly shit! hat's guy on fire (00:05:28). Di dalam kalimat tersebut terdapat dua kata slang yaitu holly shit dan on fire. Berikut ini adalah hasil penerjemahan yang dilakukan oleh partisipan pria dan wanita.

Berdasarkan hasil penerjemahan diatas bisa dilihat bahwa terdapat beberapa partisipan yang menerjemahkan kata holly shit dengan menggunakan kata yang sama, diantaranya adlalah partisipan pria 1 dan 4 yang menerjemahkan kata holly shit dengan menggunakan kata astaga. Hal sama juga terjadi pada hasil penerjemahan yang dilakukan oleh partisipan pria 3 dan partisipan wanita 7 , dan 8 yang menerjemahkan kata holly shit dengan kata sialan. Hal serupa juga terjadi pada partisipan 5 dan 6 yang memilih menggunakan kata so suci dalam menerjemahkan kata holly shit, hanya partisipan 2 yang menggunakan kata sial dalam menerjemahkan kata yang sama.

Selanjutnya adalah hasil penerjemahan kata motherfucker yang terdapat dalam kalimat let's kill this motherfucker(00:05:39) yang terdapat didalam dialog yang terdapat dalam film. Dibawah ini adalah hasil penerjemahan yang dilakukan oleh para partisipan.

Berdasarkan hasil penerjemahan di atas yang dilakukan oleh para partisipan, baik para partisipan pria dan wanita bisa dilihat bahwa terdapat banyak kesamaan dalam menerjemahkan kata slang motherfucker yang terdapat dalam kalimat let's kill this motherfucker. Terdapat kesamaan dalam menerjemahkan kata tersebut terutama yang dilakukan oleh partisipan pria 2, 3, 4 dan partisipan wanita 5, 6, 8 yang menerjemahkan kata motherfucker dengan kata bajingan, sedangkan partisipan pria 1 lebih memilih kata si brengsek dalam menerjemahkan kata tersebut, sedangkan partisipan wanita 7 memilih menggunakan kata si bangsat untuk menerjemahkan kata yang sama.

Selanjutnya adalah dua kata slang yaitu high dan fuck yang terdapat dalam kalimat that babysitter of yours is high as fuck (00:07:10). Berikut ini adalah hasil penerjemahan yang dilakukan oleh para partisipan pria dan wanita yang bisa dilihat dibawah ini.

Hasil penerjemahan yang dilakukan oleh para partisipan diatas memperlihatkan bahwa para partispan 
baik partisipan pria dan wanita cukup kesulitan dalam menerjemahkan kata high dan fuck. Partisipan pria 1 menerjemahkan kata high dengan kata cukup besar sekarang, sedangkan partisipan 2 pria memilih mengunakan kata hina dan menjijikan untuk menerjemahkan dua kata tersebut. Partisipan 3 pria memilih menggunakan kata teler sekarang untuk menerjemahkan kata yang sama. Partisipan 4 pria memilih menggunakan kata sedang makin berat untuk menerjemahkan kata high dan fuck.

Untuk para partisipan wanita juga mengalami kesulitan yang sama hal tersebut bisa dilihat dari hasil hasil penerjemahan para partisipan wanita, partisipan 5 memilih menggunakan kata sangat hina dan menjijikan untuk menerjemahkan kata as high dan fuck. Partisipan 6 wanita memilih menggunakan dua kata lebih sialan untuk menerjemahkan dua kata slang tersebut. Lain halnya dengan partispan 7 wanita yang memilih menggunakan kata mabuk berat untuk menerjemah dua kata slang tersebut, sedangkan partisipan 8 memilih kata sedang mabuk untuk menerjemahkan dua kata yang sama.

Di dalam hasil penerjemahan yang dlakukan oleh para partisipan terlihat beberapa partisipan baik partisipan pria maupun pria cukup kesulitan dalam menerjemahkan kata-kata slang yang terdapat dalam dialog yang terdapat dalam film Deadpool 2. Kesulitan-kesulitan tersebut muncul dikarenakan kurangnya pengetahuan dari para partisipan mengenai makna kata-kata slang yang terdapat dalam dialog tersebut, dan hal tersebut mempengaruhi terhadap kesetaraan makna dalam hasil penerjemahan yang dilakukan oleh para partisipan baik partisipan pria maupun wanita. Seperti yang sudah disampaikan sebelumnya terdapat empat kesetaraan, yang pertama kesetaraan pada level kata, yang kedua kesetaraan dalam tataran gramatikal, kesetaraan tekstual, dan yang terakhir adalah kesetaraan pragmatik

Untuk kesetaraan baik dalam kata, gramatikal, tekstual dan pragmatik, baik partisipan pria maupun partisipan wanita dalam menerjemahkan hampir semua mencapai partisipan telah mencapai kesetaran/kesepadanan baik pada tingkat kata, gramatikal, tekstual, dan pragmatik. Dalam kesetaraan kata totalnya adalah 52 kesetaraan dari total 8 partisipan. Sedangkan untuk kesetaraan gramatikal total kesetaraannya terdapat 44 kesetaraan/kesepadanan dari total 8 partisipan pria dan wanita. Untuk kesetaraan tekstual terdapat 51 kesetaraan dari 8 partisipan pria dan wanita. Sedangkan untuk kesetaraan pragmatik terdapat 50 kesetaraan dari total 8 partisipan pria dan wanita.

Di dalam penerjemahan yang dilakukan oleh para partispan baik mahasiswa pria maupun wanita terdapat beberapa kesetaraan dan ketidak setaraan makna. Kesetaaran yang pertama terdapat dalam hasil penerjemahan yang dilakukan oleh para partisipan adalah kesetaraan dalam level kata. Hal tersebut bisa dilihat dalam hasil penerjemahan kata fuck yang terdapat dalam prasa fuck Wolverine dalam hasil penerjemahan yang dilakukan oleh partisipan 1 memperlihatkan kesetaraan dalam level kata dengan menerjemahkan kata fuck Wolverine dengan kata persertan Wolverine dengan menerjemahkan prasa tersebut, partisipan 1 telah mencapai kesetaraan dalam level kata, karena kata persetan sacara kata dan makna telah setara dengan makna dan kata fuck.

Selain kesetaraan kata yang terdapat dalam penerjemahan dari yang dilakukan partispan pria 1, juga terdapat kesetaraan gramatikal serta kesataraan pragmatik, didalam kata persetan sendiri dalam KBBI dikelompokan sebagai partikel (kelas kata yang meliputi kata depan, kata sambung, kata seru, kata sandang, ucapan 
salam) kata seru untuk menyatakan tidak mau tahu lagi; masa bodoh; tidak peduli. Sedangkan kata fuck sendiri berdasarkan Cambridge dictionary berarti sbuah seruan atau tanda seru, yang fungsinya untuk mengungkapkan rasa marah atau menambahkan kekuatan untuk kata yang diucapkan. Dua kata tersebut yaitu fuck dan persetan mempunyai fungsi gramatikal yang sama.

Selain itu pemilihan kata tersebut memiliki kesetaraan yang lain yaitu kesetaraan tekstual dan pragmatik, secara tekstual penggunaan kata persetan untuk menerjemahkan kata fuck secara tekstual kata persetan bisa menjelaskan secara detail mengenai makna dan fungsi dari kata fuck, dari bahasa sumber yaitu bahasa Inggris, kedalam bahasa Indonesia yang merupakan bahasa target. Dalam kesetarran pragmatik pemilihan kata persetan oleh partisipan 1 dalam menerjemahkan kata fuck yang berasal dari bahasa Inggris memperliahatkan konteks situasi dalam penggunaan kata tersebut. Seperti yang telah diterangkan didalam penjelasan sebelumnya kata fuck sendiri didalam kamus digunakan sebagia tanda seru, yang biasanya digunakan untuk mengungkapkan rasa marah yang amat sangat, dan didalam cerita tersebut kata fuck dalam prasa fuck Wolverine di ucapkan oleh Deadpool kepada Wolverine untuk mengungkapkan rasa marah karena Wolverine membuat filmnya menjadi tidak menarik karena mati, dan membuat filmnya jadi kurang bersaing.

Kata slang selanjutya yang menarik dalam hasil penerjemahan kata slang yang dilakukan oleh para partisipan adalah ketika menerjemahkan dua kata slang dalam bahasa Inggris yaitu kata fuck, motherfucker, asshole dengan menggunakan kata yang sama, hal tersebut bisa dilihat dari hasil penerjemahan patisipan $2,3,4,5$ dan 6 yang menggunakan kata bajingan dalam menerjemahkan kata motherfucker yang tedapat pada kalimat let's kill this this motherfucker. Untuk kesetaraan atau kesepadanan dalam kata, kata bajingan bisa dianggap sepadan secara kata dalam menerjemahkan kata tersebut kata motherfucker maknanya dalam bahasa Inggris adalah sebuah kata offensive yang ditujukan kepada orang yang tidak disukai, sedangkan kata bajingan sendiri artinya adalah penjahat atau makian kasar pada seseorang yang tidak disukai. Dari segi gramatikal kata bajingan sendiri merupakan padanan yang setara untuk kata motherfucker, karena kedua kata tersebut mempunyai bentuk yang sama yaitu sama dalam bentuk noun.

Sedangkam untuk kesepadanan secara tekstual kata bajingan ini mempunyai kesepadanan tekstual dengan kata slang bahasa inggris yaitu motherfucker. Kesepadanan tersebut sesuai dan koheren dengan situasi dan kondisi dalam film tersebut yang akhirnya akan sesuai sepadan secara pragmatik, karena kata slang tersebut diucapkan oleh Deadpool yang merupakan karakter utama dalam film tersebut ketika dia bercerita mengenai aksinya yang akan membunuh para penjahat yang ada di sekelilingnya yang terlihat seperi gangster.

Selain kata motherfucker ada kata lain yang hampir semuanya menerjemahkan dengan kata yang sama yaitu ketika menerjemahkan kata slang gross, hampir semua partisipan kecuali partisipan 3 menggunakan kata menjijikan dalam menerjemahkan kata slang gross. Kata gross adalah untuk mengungkapkan rasa ketidaksenangan, sedangkan dalam kata jijik mempunyai makna sebagai kata seru untuk menyatakan rasa tidak suka, karena itu kedua kata tersebut mempunyai kesepadanan atau kesetaran dalam kata. Selain itu kata menjijikan dan kata gross mempunyai kesetaraan dalam gramatikal dua kata tersebut mempunyai kesepadanan atau kesetaraan dalam bentuk keduanya adalah adjektiva. 
Selain itu kata menjijikan setara dengan kata gross secara tekstual, karena memliki kesamaan dalam makna dan gramatikal dan secara kohesi menampilkan informasi yang sama antara subtitle dengan isi dialog dalam film Deadpool 2. Kata menjijikan sendiri mempunyai kesetaraan pragmatik dengan kata gross dengan isi cerita, dan konteks situasi yang terjadi dalam film, hal tersebut bisa dilihat dengan penggunaan kata gross ketika Deadpool, yang merupakan tokoh utama berdialog menyatakan rasa jijiknya ketika menghabisi para penjahat dalam film tersebut.

Ketidaksetaraan dalam hasil penerjemahan yang dilakukan oleh para partisipan dalam menerjemahkan dialog dalam film Deadpool 2, karena ketidakmampuan mencari kata yang setara dalam menerjemahkan kata slang bahasa inggris yang merupakan bahasa sumber kedalam bahasa Indonesia yang merupakan bahasa target. Contoh yang hampir semua tidak mampu dalam menerjemahkan kata slang adalah kata holy shit dalam kalimat holy shit that guy's on fire. Hampir semua partisipan menerjemahkan kata slang holy shit dengan kata sialan, so suci dan astaga. Ketiga kata tersebut kurang setara apabila digunakan dalam menerjemahkan kata holy shit. Pertama secara kesetaraan kata ketiga kata tersebut tidak setara, karena kata holy shit ada dua kata sedangkan ketiga kata tesebut adalah satu kata.

Sedangkan dalam aspek kesetaraan gramatikal kata holy shit termasuk dalam bentuk adjektiva sedangkan astaga dalam bentuk partikel, untuk kata sialan sendiri adalah noun, sedangkan kata so suci tidak diurai karena ada kata so yang seharusnya sok, dan kat sok suci ada dua kata yang berbeda secera bentuk sok adalah adverbia dan suci adalah adjektiva. Sedangkan secara kesetaraan tekstual kata astaga dan sialan tidak secara karena secara tekstual dua kata tersebut digunakan untuk kaget dan mengumpat, sedangkan kata holy shit untuk menyatakan rasa kagum dan kaget dalam waktu bersamaan. Sedangkan secara pragmatik dua kata tersebut tidak setara.

\section{KESIMPULAN}

Dalam penelitian ini terkait dengan penelitian mengenai perbedaan penerjemahan kata-kata slang yang terdapat dalam dialog dalam film Deadpool 2 yang dilakukan oleh para partisipan yang didasarkakan dari 18 kata slang dalam tujuh belas phrasa dan kalimat yang diterjemahkan oleh para partisipan dibedakan berdasarkan gender dari para penerjemah yang berjumlah 4 orang untuk masing-masing gender.

Berdasarkan data penerjemahan yang didapat dari hasil penerjemahan mahasiswa pria dan wanita diketemukan, bahwa hasil penerjemahan kata slang yang dilakukan oleh partisipan pria total terdapat 11 persamaan dalam penerjemahan kata slang dari 4 partisipan dalam menerjemahkan kata slang, dan yang diterjemahkan berbeda oleh 4 partisipan terdapat total 21 perbedaan, sedangkan pada hasil penerjemahan 4 partisipan wanita terdapat 40 persamaan dalam menerjemahkan 18 kata slang, dan terdapat 27 perbedaan dalam menerjemahkan kata-kata tersebut.

Sedangkan untuk kesetaraan baik dalam kata, gramatikal, tekstual dan pragmatik, baik partisipan pria maupun partisipan wanita dalam menerjemahkan hampir semua mencapai partisipan telah mencapai kesetaran/kesepadanan baik pada tingkat kata, gramatikal, tekstual, dan pragmatik. Dalam kesetaraan kata totalnya adalah 52 kesetaraan dari total 8 partisipan. Sedangkan untuk kesetaraan gramatikal total kesetaraannya terdapat 44 kesetaraan/kesepadanan dari total 8 partisipan pria dan wanita. Untuk kesetaraan tekstual terdapat 51 kesetaraan 
dari 8 partisipan pria dan wanita. Sedangkan untuk kesetaraan pragmatik terdapat 50 kesetaraan dari total 8 partisipan pria dan wanita.

Bebarapa ketidaksetaraan atau ketidakpadanan terjadi dikarenakan para partisipan kesulitan dalam memahami beberapa kata slang baik pada tingkatan kata, gramatikal, tekstual dan pragmatik. Hal tersebut terjadi karena para partisipan kurangnya penguasaan kosakata, sekaligus sulit mencari padanan kata dalam bahasa Indonesia karen terbatasnya perbendaharan kata-kata slang dalam bahasa Indonesia, sehingga terdapat beberapa kata slang yang diterjemahkan dengan kata yang sama dalam bahasa Indonesia.

\section{DAFTAR PUSTAKA}

Amanti, Lela (2016). The Translator's Gender and its Impact on Translation Accuracy of Narrative Style. Medwell Journal.The Social Science 11 (9). 2144-2150.

Baker, Mona. (2018). In Other Words A Course Book of Translation. New York: Routledfe.

Bell, Roger T. (1991). Translation and Translating: Theory and Practice. London: Longman.

Brodwell, D, Thompson, K. (2008). Film Art :Introduction, eight edition. New York: McGraw-Hill Company.

Catford, J. C. (1965). A Linguistic Theory of Translation. London: Oxford University Press.

Creswell, John W. (2009). Qualitative Inquiry and Research Design: Choosingamon Five Traditions. Thousand Oaks, CA: Sage.

Darlington, Yvonne and Dorothy Scott.(2002). Qualitative Research in Practice. Newsouth Wales: Allen and Unwin.
Fairus, Rani and Fauzi, Ausrazi. (2017). The Role of Gender in the Process Translation. Journal of Applied Linguistic and language Research. Vol. 4, Issue 4, 2017.

Gay, L.R., Mills, G.E. danAirasian, P.W. (2012). Educational Research. Competencies for Analysis and Applications, Tenth Edition. New Jersey: Pearson.

Halimah, Ahmad Mustafa. (2016). Gender Creative Translation: Which is better? A Case Study of Saudi Learner. International Journal of Humanities and Social Sciences. Vol 6, No.12, December 2016. 8592

Klarer, Mario (1998). An Introduction to Literary Studies. London: Routledge Newmark, Peter. (1988). A Textbook of Tranlation. London: Prentice Hall.

Nida, Eugene A. (1969). Toward A Science of Translation. Leiden: E.J.Brill.

Nugroho, Muhammad Aprianto Budie. (2018). Ananlisis Penerjemahan Kata-Kata Slang Dalam Hasil Penerjemahan Film Austin Power; The Spy Who Shagged Me. Fon. Vol 12, No. 1, 2018. 27-38

Santika, Dwi. (2015). The Translation Strategy of Slang Expression in Comic Entitled The Punisher. AlTuras. Vol. XXI, No. 1, Januari 2015. 127-144

Spolsky, Bernard. (1998). Sociolinguistic. Oxford: Oxford University Press

Vassiliou, A. (2006). Analysis Film Content: a text-based approach. Department of Computing School of Electronoc and Physical Sciences, University of Surrey. Guildford: UK. 